\title{
Prediction of diametric and dynamic structures in a semiarid forest (Caatinga) area submitted to Forest Management, Brazil ${ }^{1}$
}

\author{
Adriano Castro de Brito', Alessandro de Paula $*$ (D), Patrícia Anjos Bittencourt Barreto-Garcia ${ }^{3}$, \\ Deoclides Ricardo Souza ${ }^{4}$, Robson Borges de Lima ${ }^{5}$ \\ 10.1590/0034-737X202269010012
}

\begin{abstract}
Dynamics studies associated with prognosis can support planning actions for the conservation and sustainable use of forest resources. Therefore, the objective of this study was to evaluate the dynamics and predict the diameter structure using the Markov chain model for an area of caatinga forest submitted to different management practices. The study was carried out in the Contendas do Sincorá National Forest in the state of Bahia. Four treatments were installed, corresponding to three management systems and one control. Data was obtained measuring all individuals with a diameter greater than or equal to $5 \mathrm{~cm}$. The measurements were performed at two moments in 2015 and 2018 . The results indicated that the selective cut-by-diameter treatment had the lowest mortality rate and the highest recruitment rate. Predictions of the diameter structure using the Markov chain do not generally present statistical differences $\left(\alpha_{0.01}\right)$ between the observed and expected frequencies for the year 2018. It was concluded that the basal area showed a tendency for recovery and growth in the treatments which involved suppression compared to the control, with no statistically significant differences among treatments until the moment after intervention.
\end{abstract}

Keywords: Markov chain; forest dynamics; Contendas do Sincorá National Forest; prognosis.

\section{INTRODUCTION}

The Caatinga biome occupies an area equivalent to $11 \%$ of the Brazilian territory and encompassing most of the Northeast states and the North of Minas Gerais (Guerra et al., 2014; IBGE, 2019). In addition, this biome is considered a unique ecosystem, presenting a significant number of rare and endemic taxa (Ferraz et al., 2013; Pereira Junior et al., 2014). The caatinga also presents a great diversity of phytophysiognomies due to different precipitation and soil patterns (Pereira Junior et al., 2014).

Despite some studies already having been conducted, little is known about understanding the Caatinga, especially how to use the available forest resources offered by this biome in order to maintain its regeneration cycle and thus be exploited once again (Vasconcelos et al., 2017). Garlet et al. (2018) highlighted that one of the main exploitive actions of Caatinga vegetation is removing firewood. Campello (2019) revealed that firewood has a $33 \%$ share in the energy matrix of the Northeast region, often it being removed through unsustainable exploitation.

However, one way of using the available resources in a sustainable way is through implementing sustainable forest management, as provided by law in Brazil (no. 11,284, dated 03.20.2006, Article 3). Management practices seek to obtain economic benefits, in social and environmental aspects, while respecting the mechanisms which support the ecosystem, as well as continuous obtaintion of products and service goods which the forest can offer, ensuring its productive capacity (Brazil, 2006; Gariglio et al., 2010).

One way to sustainably assist forest planning is through production models. It is possible to predict important information for making management decisions by applying growth models (Peng, 2000).

\footnotetext{
Submitted on July 16th, 2020 and accepted on April 20th, 2021.

This work is part of the first author's Master Dissertation.

2Universidade Estadual do Sudoeste da Bahia, Programa de Pós-Graduação em Ciências Florestais, Vitória da Conquista, Bahia, Brazil. acbrito.eng@gmail.com

3Universidade Estadual do Sudoeste da Bahia, Departamento de Engenharia Agrícola e Solos, Vitória da Conquista, Bahia, Brazil. apaula@uesb.edu.br; patriciabarreto@uesb.edu.br

4Universidade Federal do Recôncavo da Bahia, Centro de Ciências Agrárias, Ambientais e Biológicas, Cruz das Almas, Bahia, Brazil. drsouza@ufrb.edu.br

5Universidade do Estado do Amapá, Departamento de Engenharia Florestal, Macapá, Amapá, Brazil. rb_florestal@yahoo.com.br

*Corresponding author: apaula@uesb.edu.br
}

Rev. Ceres, Viçosa, v. 69, n.1, p. 92-101, jan/feb, 2022 
The Markov chain is one of the models used to evaluate production in native forests. The Markovian method is a stochastic process and assumes that a tree of a given diameter class is likely to move to another class starting from its current state (Lana et al., 2015).

The Markov chain has also been applied in modeling the dynamic processes of native forests to conduct projections of the forest structure (Souza \& Soares, 2013). The study of dynamics is based on the idea of recruitment, mortality and growth over time; therefore, studies on dynamics can provide understanding on the processes through which changes occur in both species levels and in the forest community as a whole (Figueiredo Filho et al., 2010).

Given the above, the present study aimed to evaluate the forest dynamics and predict the diameter structure in a Caatinga area submitted to different forest management practices.

\section{MATERIALAND METHODS}

The study was carried out in the Contendas do Sincorá National Forest (FLONA Contendas do Sincorá), located in the municipality of Contendas do Sincorá, Bahia, Brazil, at the coordinates: $13^{\circ} 55^{\prime} 21^{\prime \prime}$ south latitude and $41^{\circ} 06^{\prime} 57^{\prime \prime}$ West longitude (Figure 1). It is also possible to verify the distribution of the experimental units and their respective treatments used in Figure 1.

The climate of the region is semi-arid (BSwh) according to the Köeppen classification, it being described as a hot climate with scarce and irregular rains concentrated in the summer. The average annual temperature is $23^{\circ} \mathrm{C}$ and rainfall is between $596 \mathrm{~mm}$ and $679 \mathrm{~mm}$ per year, distributed between the months of November to April (IBAMA, 2006). The soil of the study area is Red-Yellow Argisol (IBAMA, 2006). The vegetation is classified as Forest-steppe Savanna (IBGE, 2012).

The work was carried out in a previously demarcated area in which three experimental units with 16 plots each of $20 \times 20 \mathrm{~m}$ were installed in 2015 . Four treatments were also installed in 2015, corresponding to three management systems and one unmanaged Caatinga condition.

The first measurement was performed in the experimental units in 2015 using a caliper by which all individuals with a diameter at breast height greater than or equal to $5.0 \mathrm{~cm}(\mathrm{DBH}=5.0 \mathrm{~cm})$ were measured at $1.30 \mathrm{~m}$ aboveground from soil.

The treatments adopted were: a) shallow cut (SC) which consisted of felling all trees and shrubs; b) selective cutting by minimum diameter (SCDBH) - felling all trees with DBH greater than or equal to $5.0 \mathrm{~cm}$; c) selective cutting by species (SCS) - felling the three species of trees with greater occurrence in the area (Commiphora leptophloeos (Mart.) J. B. Gillett, Jatropha molissima (Pohl) Baill and Pseudobombax simplicifolium A. Robyns); and d) control (C) - corresponds to the unmanaged Caatinga. Each treatment was distributed in four replications within each sample unit.

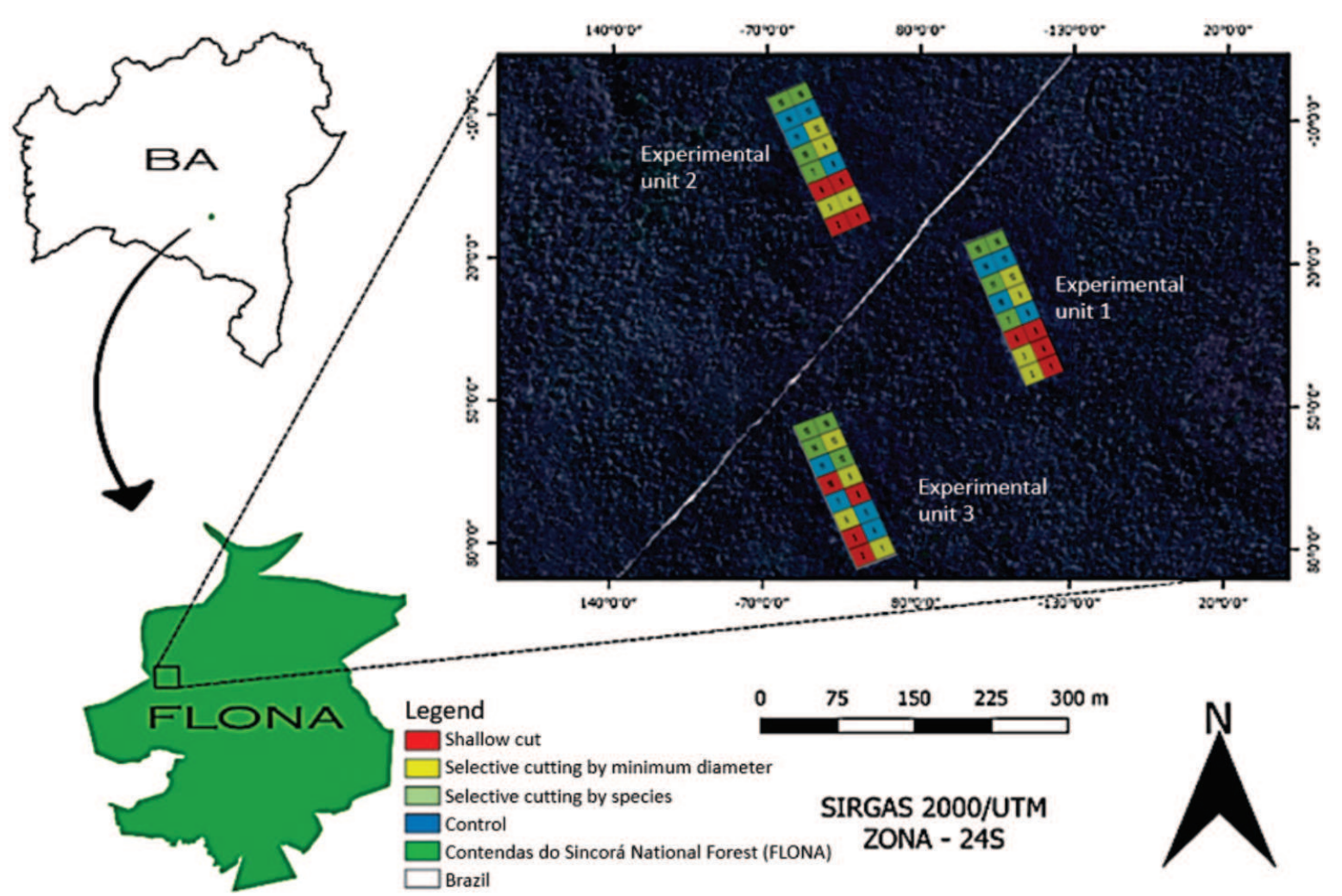

Figure 1: Map of Location and distribution of experimental units, Contendas do Sincorá National Forest, Bahia, Brazil. 
It is worth mentioning that the Spondias tuberosa Arruda and Myracrodruon urundeuva Allemão species were not suppressed, as provided by law in treatments involving cutting (Decree No. 15180, 2014). Thus, only these species were considered for the purpose of comparing the SCDBH treatment in order to verify the effect of treatments on growth rates.

The second measurement of the experiment was performed in 2018 following the same criteria as the first survey in order to evaluate the dynamic processes. Thus, the trees which left the system were computed, meaning dead individuals and those which had entered and had reached the established minimum diameter. An analysis on the evolution of the basal area among treatments was performed through Analysis of Variance (ANOVA) at 95\% probability.

Next, mortality rates, income and periodic increments were calculated to assess forest dynamics.

The diameter growth, the annual periodic increment, the mortality rate and the recruitment rate, was calculated using the expressions of Souza \& Soares (2013).

Next, the data obtained on the first $(\mathrm{t} 0=2015)$ and second $(t+1=2018)$ measurement occasions were considered to predict the diameter distribution. The diameter distribution was projected for the years 2018 and 2021, and for 2018 it was compared with the actual distribution obtained in the second measurement.

The transition probabilities $\left(a_{i}, b_{i}, c_{i}\right.$ and $\left.m_{i}\right)$ related to the transition between one state and another were calculated for the recruitments into the matrix by the expression [1].

$P_{\mathrm{ij}}=\frac{n_{\mathrm{ij}}}{n_{\mathrm{i}}}$

In which:

$P_{\mathrm{ij}}=$ transition probability $\left(a_{\mathrm{i}}, b_{\mathrm{i}}, c_{\mathrm{i}}\right.$ and $\left.m_{\mathrm{i}}\right)$;

$n_{\mathrm{ij}}=$ number of trees in state $j$, at time $t+1$, given in class $i$, at time $t$;

$n_{i}=$ total number of individuals in state $i$, in time $\mathrm{t}$.

The matrix $\mathrm{G}$ was then obtained based on the transition of each projection period, which means the probabilistic transition matrix, and it was constructed as follows (Buongiorno \& Michie, 1980):

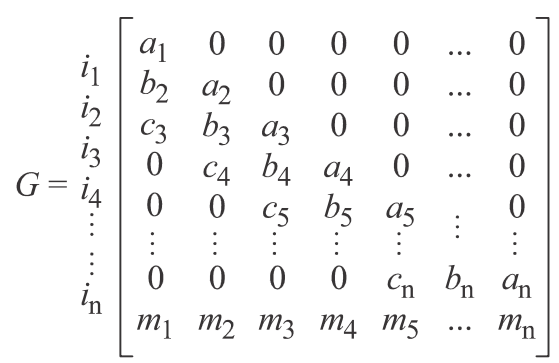

In which:

$G=$ probabilistic transition matrix;

$i=$ diameter class;

$a_{i}, b_{i}$ and $c_{i}=$ probabilities that a live tree will remain in the same diameter class, change one class and/or change two classes, respectively;

$m_{i}=$ probability of trees die in the monitored period.

Therefore, the projection of the forest's diametric structure can be estimated for one stage $(t+1)$ and for two stages $(\mathrm{t}+2)$ using the expressions [2] and [3], respectively (Buongiorno \& Michie, 1980; Azevedo et al., 1995).

$$
\begin{aligned}
& N_{1 \theta}=G \cdot N_{0}+C_{1} \\
& N_{2 \theta}=G^{2} \cdot N_{0}+C_{2}
\end{aligned}
$$

In which:

$N_{1 \theta}=$ number of predicted trees;

$\mathrm{G}=$ probabilistic transition matrix;

$N_{o}=$ frequency of the number of trees per diameter class (t);

$C_{1}=$ column vector of the number of trees entered.

Thus, the estimated diameter distribution for 2018 and 2021 was verified to evaluate the forecasts based on the projections of the diameter class distributions through the Markov chain, while for 2018 it was observed from the actual data collected in 2018. The Chi-squared statistical test $\left(X^{2}\right)$ was used at $1 \%\left(a_{0.01}\right)$ significance level for both.

The test assumes that: if the calculated $X^{2}$ is less than the tabulated value, there is no significant difference between the observed and predicted frequencies for the diameter distribution in each diameter class.

It should be noted that the SC treatment in 2018 did not present individuals within the inclusion limit. Therefore, this information only refers to the SCDBH, SCS and the control treatments.

\section{RESULTS}

Table 1 shows the behavior of the basal area before the intervention, in the remaining stock and in the last measurement period (2018). After the three years of intervention it was found that there was no significant difference among treatments for the basal area by analysis of variance at $95 \%$ probability (Table 2).

Thus, it is noted that the basal area showed a growth trend after three years, regardless of the type of intervention.

For dynamics, the control presented annual mortality rates of $5.02 \%$ and recruitment rates of $5.10 \%$. The mortality rate in the SCS treatment was higher than the recruitment rate, $12.78 \%$ and $5.84 \%$ respectively. The SCDBH treatment had the lowest mortality rate $(0.81 \%)$ and the highest recruitment rate $(29.28 \%)$ (Table 3$)$. 
It was verified that there was an accentuated dynamic in all performed treatments, meaning that there was entry and exit movement of individuals in the system. This movement was largely due to mortality and recruitment rates.

The registered mortality was higher in the SCS and the control treatments with 73 and 26 individual.ha ${ }^{-1}$, respectively. We highlight the high mortality rates in individuals of Manihot catingae Ule (20.43\%) for the SCS treatment and Patagonula bahiensis Moric. (25.86\%) in the control treatment.

These high mortality rates may have been due to the fact that these species are intolerant to high light incidence or due to the very high competition which exists among individuals, since the SCS and the control treatments continued with a high density of individuals in their units even after undergoing intervention.

The annual periodic increment (API) was $0.4097 \mathrm{~cm}_{\text {.year }}{ }^{-1}$, ranging from $0.0333 \mathrm{~cm}$.year ${ }^{-1}$ to $5.4 \mathrm{~cm}$.year ${ }^{-1}$ for the species inventoried in the control treatment. Meanwhile, the increase for the SCS treatment was $0.2950 \mathrm{~cm}^{\text {.year }}{ }^{-1}$, ranging from 0.3333 $\mathrm{cm}$ year ${ }^{-1}$ to $4.2667 \mathrm{~cm}$.year ${ }^{-1}$. The SCDBH treatment showed an increase of $0.0707 \mathrm{~cm}$.year ${ }^{-1}$, varying from $0.3333 \mathrm{~cm}^{\text {year }}{ }^{-1}$ to $0.1333 \mathrm{~cm}$.year ${ }^{-1}$.

The values found in this study are similar to those obtained in the experimental stations which compose the Caatinga forest management network. These showed a variation in the average annual increment between the experimental units from 0.03 to $10.9 \mathrm{~m}^{3}$ (Riegelhaupt et al., 2010).

The species which showed the highest increase rate in the control treatment were: Commiphora leptophloeos (Mart.) J.B. Gillett (2.6 cm.year $\left.{ }^{-1}\right)$; Cordia americana (L.) Gottschling \& J.S.Mill. (1.7 cm.year $\left.{ }^{-1}\right)$; and Pseudobombax simplicifolium A. Robyns (1.3 cm.year-1).

The species which showed the highest increase rate for the SCS treatment were: Handroanthus selachidentatus (A.H.Gentry) S.Grose (0.79 cm.year $\left.{ }^{-1}\right)$; Coccoloba alnifolia Casar. $\left(0.77 \mathrm{~cm}_{\text {.year }}{ }^{-1}\right)$; and Mimosa acutistipula var. ferrea Barneby $\left(0.67 \mathrm{~cm}\right.$ year $\left.^{-1}\right)$.

When comparing the influence of treatments on the growth dynamics of the Myracrodruon urundeuva and Spondias tuberosa species (the only ones present in the three treatments), it was observed that the SCS most influenced the increase in diameter.

Regarding the projection of the diametric structure for the monitored period, Tables 4, 5 and 6 showed the absolute number of individuals and the changing behavior in the number of individuals for the diameter classes according to each treatment, with emphasis on the number of recruited trees for the SCDBH treatment.

It appears that the mortality status (M) varied according to each treatment, with the control presenting 26 individuals during the monitored period. In addition, the highest concentration $(46.15 \%)$ was in the first diametric class. For the SCS treatment, state (M) had 73 individuals, as $71.23 \%$ of those which left the system belonged to the first class. For the SCDBH treatment, the state (M) presented only two individuals, corresponding to $0.04 \%$, with all belonging to the first diametric class.

The initial transition probability matrix for each treatment was obtained from the absolute values in Tables 4, 5 and 6, whose elements are presented in Tables 7, 8 and 9. It is also possible to observe the probabilities of a tree to change, remain or leave the system according to the diameter class in Tables 7, 8 and 9.

Table 2: Analysis of variance for the dynamics of the basal area in 2018, Contendas do Sincorá National Forest, Bahia, Brazil

\begin{tabular}{lcccc}
\hline Variation cause & GL & S Q & QM & F \\
\hline Treatments & 2 & 3.45509 & 1.72755 & $0.58^{\text {ns }}$ \\
Residual & 6 & 1.77901 & 2.96502 & \\
Total & 8 & 5.2341 & - & \\
\hline
\end{tabular}

Table 3: Estimate of the analyzed parameters in the monitoring carried out in 2015-2018, Contendas do Sincorá National Forest, BA, Brazil

\begin{tabular}{lccc}
\hline Parameters & \multicolumn{3}{c}{$\mathbf{2 0 1 8}$} \\
\cline { 2 - 4 } & $\mathbf{C}$ & $\mathbf{S C S}$ & $\mathbf{S C D B H}$ \\
\hline Mortality rate $(\%)$ & 5.02 & 12.78 & 0.81 \\
Entrance rate $(\%)$ & 5.10 & 5.84 & 29.28 \\
Annual periodic & 0.4097 & 0.2950 & 0.0707 \\
increment $\left(\mathrm{cm}\right.$. year $\left.^{-1}\right)$ & & & \\
\hline
\end{tabular}

In which: C - Control; SCS - Selective cutting by species; SCDBH Selective cutting by diameter $(\mathrm{DBH} \geq 5 \mathrm{~cm})$.

Table 1: Basal area dynamics in an experimental unit submitted to different forest management practices, Contendas do Sincorá National Forest, Bahia, Brazil

\begin{tabular}{lccc}
\hline Treatment & $\begin{array}{c}\text { Basal area } \\
\text { (prior to the intervention) }\end{array}$ & $\begin{array}{c}\text { Remaining basal area } \\
\mathbf{( 2 0 1 5 )}\end{array}$ & $\begin{array}{c}\text { Basal area } \\
\text { in 2018 }\end{array}$ \\
\hline CDAP & 4.0962 & $1.1624 *$ & 2.1068 \\
SCS & 3.6503 & 1.5491 & 3.1740 \\
C & 3.5219 & 3.5219 & 3.7436 \\
\hline
\end{tabular}

In which: C - Control (C1); SCS - Selective cutting by species (C2); SCDBH - Selective cutting by diameter (DBH $\geq 5 \mathrm{~cm})(\mathrm{C} 3) . *$ Basal area of the cut immune species. 
In Table 7, the main diagonal of the control treatment matrix shows that the probability of a tree in the $5-8 \mathrm{~cm}$ diameter class remaining in the same class after three years is 0.9071 ; the probability of the individual in this same class growing to the next (secondary diagonal) class of $8-11 \mathrm{~cm}$ is 0.0557 ; and the probability of a tree die in this class $(5-8 \mathrm{~cm})$ in three years is 0.0371 . The same understanding follows for the SCS and SCDBH treatments, and the transition probability matrix elaborated for these treatments can be seen in Tables 8 and 9 , respectively.

In Table 9, zero probability occurred in the classes of the matrix main diagonal. This means that an absorbent state occurred for projection purposes.

Looking at Tables 7, 8 and 9, a prediction of the diametric structure was calculated, which it is a projection between the classes of observed frequencies and the prediction for each of the treatments.

Table 4: Number of trees which changed from state $(i)$ to another state $(j)$, in the control treatment by diameter class in the period from 2015 (t) to 2018 (t+1), Contendas do Sincorá National Forest, Bahia, Brazil. In which: $\mathrm{M}=$ mortality; $\mathrm{R}=$ recruitment; and Next $=$ next class

\begin{tabular}{|c|c|c|c|c|c|c|c|c|c|c|c|c|c|c|c|}
\hline \multirow{2}{*}{\multicolumn{2}{|c|}{$\begin{array}{l}\text { Class center } \\
\text { DBH }\end{array}$}} & \multicolumn{13}{|c|}{ States in 2015} & \multirow{2}{*}{ Total $(t+1)$} \\
\hline & & I & 6,5 & 9,5 & 12,5 & 15,5 & 18,5 & 21,5 & 24,5 & 27,5 & 30,5 & $>32$ & Next & $\mathbf{M}$ & \\
\hline & 6,5 & 31 & 280 & & & & & & & & & & & & 311 \\
\hline \multirow{11}{*}{ 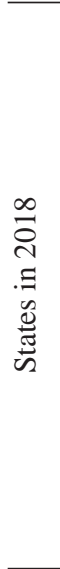 } & 9,5 & & 18 & 75 & & & & & & & & & & & 93 \\
\hline & 12,5 & & & 5 & 31 & & & & & & & & & & 36 \\
\hline & 15,5 & & & & 3 & 13 & & & & & & & & & 16 \\
\hline & 18,5 & & & & & & 7 & & & & & & & & 7 \\
\hline & 21,5 & & & & & & & 3 & & & & & & & 3 \\
\hline & 24,5 & & & & & & & & 1 & & & & & & 1 \\
\hline & 27,5 & & & & & & & & & 1 & & & & & 1 \\
\hline & 30,5 & & & & & & & & & & 0 & & & & 0 \\
\hline & $>32$ & & & & & & & & & & & 1 & & & 1 \\
\hline & Next & & & & & & & & & & & & & & 0 \\
\hline & M & & 52 & 14 & 3 & 2 & 1 & 0 & 0 & 0 & 1 & 0 & & & 73 \\
\hline \multicolumn{2}{|c|}{ Total (t) } & 31 & 350 & 94 & 37 & 15 & 8 & 3 & 1 & 1 & 1 & 1 & - & - & 542 \\
\hline
\end{tabular}

Table 5: Number of trees that changed from state $(i)$ to another state $(j)$ in the selective cutting treatment by species by diameter class in the period from $2015(\mathrm{t})$ to $2018(\mathrm{t}+1)$, Contendas do Sincorá National Forest, Bahia, Brazil. In which: $\mathrm{M}=$ mortality; $\mathrm{R}=$ recruitment; and Next $=$ next class

\begin{tabular}{|c|c|c|c|c|c|c|c|c|c|c|c|c|c|c|c|}
\hline \multirow{2}{*}{\multicolumn{2}{|c|}{$\begin{array}{l}\text { Class center } \\
\text { DBH }\end{array}$}} & \multicolumn{13}{|c|}{ States in 2015} & \multirow{2}{*}{ Total $(t+1)$} \\
\hline & & I & 6,5 & 9,5 & 12,5 & 15,5 & 18,5 & 21,5 & 24,5 & 27,5 & 30,5 & $>32$ & Next & $\mathbf{M}$ & \\
\hline & 6,5 & 27 & 293 & & & & & & & & & & & & 320 \\
\hline \multirow{11}{*}{ 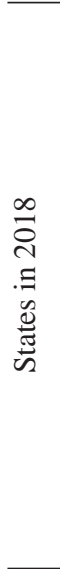 } & 9,5 & & 18 & 79 & & & & & & & & & & & 97 \\
\hline & 12,5 & & & 6 & 30 & & & & & & & & & & 36 \\
\hline & 15,5 & & & & & 14 & & & & & & & & & 14 \\
\hline & 18,5 & & & & & & 5 & & & & & & & & 5 \\
\hline & 21,5 & & & & & & & 6 & & & & & & & 6 \\
\hline & 24,5 & & & & & & & & 2 & & & & & & 2 \\
\hline & 27,5 & & & & & & & & & 2 & & & & & 2 \\
\hline & 30,5 & & & & & & & & & & 2 & & & & 2 \\
\hline & $>32$ & & & & & & & & & & & 1 & & & 1 \\
\hline & Next & & & & & & & & & & & & & & 0 \\
\hline & $\mathrm{M}$ & & 12 & 10 & 3 & 1 & & & & & & & & & 26 \\
\hline \multicolumn{2}{|c|}{ Total (t) } & 27 & 323 & 95 & 33 & 15 & 5 & 6 & 2 & 2 & 2 & 1 & - & - & 511 \\
\hline
\end{tabular}

Rev. Ceres, Viçosa, v. 69, n.1, p. 92-101, jan/feb, 2022 
Tables 10, 11 and 12 show the number of trees by real diameter class and predicted by the Markovian method for the control, SCS and SCDBH treatment, respectively.

As observed by the chi-squared test $\left(X^{2}\right)$ at $95 \%$ probability, there was no difference between the observed and estimated frequencies for the prediction performed for the year 2018 to the SCS, SCDBH and control treatments, despite presenting some underestimates and overestimates along the class centers.
The Markovian method proved to be efficient for the projections, meaning that the predicted diameter distribution for each treatment is statistically equal to the real distribution for the year 2018.

As observed in the prediction, the treatments are in progress after the intervention with regarding basal area, the recruitment of new individuals and the species growth, which it suggests that the stock is being replenished after three years from the recruitment of these new individuals.

Table 6: Number of trees which changed from state $(i)$ to another state $(j)$ in the selective cutting treatment by diameter (DBH $\geq 5$ $\mathrm{cm}$ ) by diameter class in the period from 2015 (t) to $2018(\mathrm{t}+1)$, Contendas do Sincorá National Forest, Bahia, Brazil. In which: M $=$ mortality; $\mathrm{R}=$ recruitment; and Next $=$ next class

\begin{tabular}{|c|c|c|c|c|c|c|c|c|c|c|c|c|c|c|c|}
\hline \multirow{2}{*}{\multicolumn{2}{|c|}{$\begin{array}{l}\text { Class center } \\
\text { DBH }\end{array}$}} & \multicolumn{13}{|c|}{ States in 2015} & \multirow{2}{*}{ Total $(t+1)$} \\
\hline & & I & 6,5 & $\mathbf{9 , 5}$ & 12,5 & 15,5 & 18, & 21,5 & 24,5 & 27,5 & 30,5 & $>32$ & Next & $\mathbf{M}$ & \\
\hline & 6,5 & 98 & 132 & & & & & & & & & & & & 230 \\
\hline \multirow{11}{*}{ 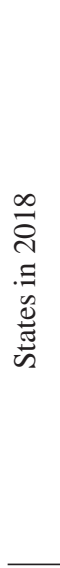 } & 9,5 & 3 & & 58 & & & & & & & & & & & 61 \\
\hline & 12,5 & & & & 20 & & & & & & & & & & 20 \\
\hline & 15,5 & & & & & 14 & & & & & & & & & 14 \\
\hline & 18,5 & & & & & & 6 & & & & & & & & 6 \\
\hline & 21,5 & & & & & & & 9 & & & & & & & 9 \\
\hline & 24,5 & & & & & & & & 1 & & & & & & 1 \\
\hline & 27,5 & & & & & & & & & 0 & & & & & 0 \\
\hline & 30,5 & & & & & & & & & & 0 & & & & 0 \\
\hline & $>32$ & & & & & & & & & & & 0 & & & 0 \\
\hline & Next & & & & & & & & & & & & & & 0 \\
\hline & $\mathrm{M}$ & & 2 & & & & & & & & & & & & 2 \\
\hline \multicolumn{2}{|c|}{ Total (t) } & 101 & 134 & 58 & 20 & 14 & 6 & 9 & 1 & 0 & 0 & 0 & - & - & 343 \\
\hline
\end{tabular}

Table 7: Initial transition probability matrix (P) for the control treatment by diameter class in the period from 2015 to 2018 , Contendas do Sincorá National Forest, Bahia, Brazil. In which: $\mathrm{M}=$ mortality; R = recruitment; and Next = next class

\begin{tabular}{|c|c|c|c|c|c|c|c|c|c|c|c|c|c|c|}
\hline \multirow{2}{*}{\multicolumn{2}{|c|}{$\begin{array}{l}\text { Class center } \\
\text { DBH }\end{array}$}} & \multicolumn{13}{|c|}{ States in 2015} \\
\hline & & \multirow{2}{*}{$\begin{array}{l}\mathbf{I} \\
1\end{array}$} & \multirow{2}{*}{$\begin{array}{c}\mathbf{6 , 5} \\
0,9071\end{array}$} & \multirow{2}{*}{$\begin{array}{c}\mathbf{9 , 5} \\
0\end{array}$} & \multirow{2}{*}{$\begin{array}{c}\mathbf{1 2 , 5} \\
0\end{array}$} & \multirow{2}{*}{$\begin{array}{c}\mathbf{1 5 , 5} \\
0\end{array}$} & \multirow{2}{*}{$\begin{array}{c}\mathbf{1 8 , 5} \\
0\end{array}$} & \multirow{2}{*}{$\begin{array}{c}\mathbf{2 1 , 5} \\
0\end{array}$} & \multirow{2}{*}{\begin{tabular}{|c|}
$\mathbf{2 4 , 5}$ \\
0
\end{tabular}} & \multirow{2}{*}{$\begin{array}{c}\mathbf{2 7 , 5} \\
0\end{array}$} & \multirow{2}{*}{$\begin{array}{c}\mathbf{3 0 , 5} \\
0\end{array}$} & \multirow{2}{*}{$\begin{array}{c}>32 \\
0\end{array}$} & \multirow{2}{*}{\begin{tabular}{|c|} 
Next \\
0
\end{tabular}} & \multirow{2}{*}{$\frac{\mathbf{M}}{0}$} \\
\hline \multirow{12}{*}{ 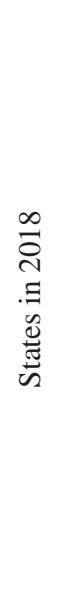 } & 6,5 & & & & & & & & & & & & & \\
\hline & 9,5 & 0 & 0,0557 & 0,8316 & 0 & 0 & 0 & 0 & 0 & 0 & 0 & 0 & 0 & 0 \\
\hline & 12,5 & 0 & 0 & 0,0631 & 0,9091 & 0 & 0 & 0 & 0 & 0 & 0 & 0 & 0 & 0 \\
\hline & 15,5 & 0 & 0 & 0 & 0 & 0,9333 & 0 & 0 & 0 & 0 & 0 & 0 & 0 & 0 \\
\hline & 18,5 & 0 & 0 & 0 & 0 & 0 & 1 & 0 & 0 & 0 & 0 & 0 & 0 & 0 \\
\hline & 21,5 & 0 & 0 & 0 & 0 & 0 & 0 & 1 & 0 & 0 & 0 & 0 & 0 & 0 \\
\hline & 24,5 & 0 & 0 & 0 & 0 & 0 & 0 & 0 & 1 & 0 & 0 & 0 & 0 & 0 \\
\hline & 27,5 & 0 & 0 & 0 & 0 & 0 & 0 & 0 & 0 & 1 & 0 & 0 & 0 & 0 \\
\hline & 30,5 & 0 & 0 & 0 & 0 & 0 & 0 & 0 & 0 & 0 & 1 & 0 & 0 & 0 \\
\hline & $>32$ & 0 & 0 & 0 & 0 & 0 & 0 & 0 & 0 & 0 & 0 & 1 & 0 & 0 \\
\hline & Next & 0 & 0 & 0 & 0 & 0 & 0 & 0 & 0 & 0 & 0 & 0 & 0 & 0 \\
\hline & $M$ & 0 & 0,0371 & 0,1051 & 0,0909 & 0,0667 & 0 & 0 & 0 & 0 & 0 & 0 & 0 & 0 \\
\hline \multicolumn{2}{|c|}{ Total (t) } & 1 & 1 & 1 & 1 & 1 & 1 & 1 & 1 & 1 & 1 & 1 & 0 & 0 \\
\hline
\end{tabular}




\section{DISCUSSION}

In the specific case of the SCS treatment, the fact that the mortality rate is higher than recruitment does not necessarily indicate that there was a decrease, but rather a response to the type of intervention which occurred in this treatment. The mortality rate behavior being higher than recruitment was observed for other studies in different biomes and regions (Oliveira-Filho et al., 2007; Pantaleão et al., 2008; Colpini et al., 2010; Miguel et al., 2011; Santos et al., 2012).
Therefore, the results for mortality found in this study corroborate those of Lingner et al. (2007), Shen et al. (2013) and Sawczuk et al. (2012), who found that mortality rate was directly influenced by the populations with the highest density, showing the competition among individuals.

In analyzing two types of treatments (shallow cutting with restriction and selective cutting by diameter $>3 \mathrm{~cm}$ ) in the Caatinga area in the municipality of Mossoró/RN, Araújo \& Silva (2010b) verified trends in growth with a

Table 8: Transition probability matrix (P) for the selective cutting treatment by species by diameter class in the period from 2015 to 2018, Contendas do Sincorá National Forest, Bahia, Brazil. In which: $\mathrm{M}=$ mortality; $\mathrm{R}=$ recruitment; and Next = next class

\begin{tabular}{|c|c|c|c|c|c|c|c|c|c|c|c|c|c|c|}
\hline \multirow{2}{*}{\multicolumn{2}{|c|}{$\begin{array}{l}\text { Class center } \\
\text { DBH }\end{array}$}} & \multicolumn{13}{|c|}{ States in 2015} \\
\hline & & I & 6,5 & 9,5 & 12,5 & 15,5 & 18,5 & 21,5 & 24,5 & 27,5 & 30,5 & $>32$ & Next & M \\
\hline \multirow{12}{*}{ 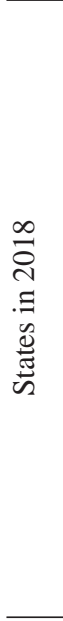 } & 6,5 & 1 & 0,8 & 0 & 0 & 0 & 0 & 0 & 0 & 0 & 0 & 0 & 0 & 0 \\
\hline & 9,5 & 0 & 0,0514 & 0,7979 & 0 & 0 & 0 & 0 & 0 & 0 & 0 & 0 & 0 & 0 \\
\hline & 12,5 & 0 & 0 & 0,0532 & 0,8378 & 0 & 0 & 0 & 0 & 0 & 0 & 0 & 0 & 0 \\
\hline & 15,5 & 0 & 0 & 0 & 0,0811 & 0,8667 & 0 & 0 & 0 & 0 & 0 & 0 & 0 & 0 \\
\hline & 18,5 & 0 & 0 & 0 & 0 & 0 & 0,875 & 0 & 0 & 0 & 0 & 0 & 0 & 0 \\
\hline & 21,5 & 0 & 0 & 0 & 0 & 0 & 0 & 1 & 0 & 0 & 0 & 0 & 0 & 0 \\
\hline & 24,5 & 0 & 0 & 0 & 0 & 0 & 0 & 0 & 1 & 0 & 0 & 0 & 0 & 0 \\
\hline & 27,5 & 0 & 0 & 0 & 0 & 0 & 0 & 0 & 0 & 1 & 0 & 0 & 0 & 0 \\
\hline & 30,5 & 0 & 0 & 0 & 0 & 0 & 0 & 0 & 0 & 0 & 0 & 0 & 0 & 0 \\
\hline & $>32$ & 0 & 0 & 0 & 0 & 0 & 0 & 0 & 0 & 0 & 0 & 1 & 0 & 0 \\
\hline & Next & 0 & 0 & 0 & 0 & 0 & 0 & 0 & 0 & 0 & 0 & 0 & 0 & 0 \\
\hline & M & & 0,1486 & 0,1489 & 0,0811 & 0,1333 & 0,125 & 0 & 0 & 0 & 1 & 0 & 0 & 0 \\
\hline \multicolumn{2}{|c|}{ Total (t) } & 1 & 1 & 1 & 1 & 1 & 1 & 1 & 1 & 1 & 1 & 1 & 0 & 0 \\
\hline
\end{tabular}

Table 9: Transition probability matrix $(\mathrm{P})$, for the selective cut treatment by diameter $(\mathrm{DBH}>5 \mathrm{~cm})$, by diameter class, in the period from 2015 to 2018, Contendas do Sincorá National Forest, Bahia, Brazil. In which: M = mortality; R = recruitment; and Next = next class

\begin{tabular}{|c|c|c|c|c|c|c|c|c|c|c|c|c|c|c|}
\hline \multirow{2}{*}{\multicolumn{2}{|c|}{$\begin{array}{l}\text { Class center } \\
\text { DBH }\end{array}$}} & \multicolumn{13}{|c|}{ States in 2015} \\
\hline & & I & 6,5 & 9,5 & 12,5 & 15,5 & 18,5 & 21,5 & 24,5 & 27,5 & 30,5 & $>32$ & Next & $\mathbf{M}$ \\
\hline \multirow{12}{*}{ 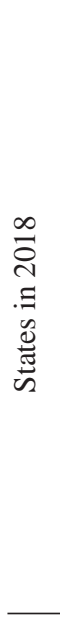 } & 6,5 & 0,9703 & 0,9845 & 0 & 0 & 0 & 0 & 0 & 0 & 0 & 0 & 0 & 0 & 0 \\
\hline & 9,5 & 0,0297 & 0 & 1 & 0 & 0 & 0 & 0 & 0 & 0 & 0 & 0 & 0 & 0 \\
\hline & 12,5 & 0 & 0 & 0 & 1 & 0 & 0 & 0 & 0 & 0 & 0 & 0 & 0 & 0 \\
\hline & 15,5 & 0 & 0 & 0 & 0 & 1 & 0 & 0 & 0 & 0 & 0 & 0 & 0 & 0 \\
\hline & 18,5 & 0 & 0 & 0 & 0 & 0 & 1 & 0 & 0 & 0 & 0 & 0 & 0 & 0 \\
\hline & 21,5 & 0 & 0 & 0 & 0 & 0 & 0 & 1 & 0 & 0 & 0 & 0 & 0 & 0 \\
\hline & 24,5 & 0 & 0 & 0 & 0 & 0 & 0 & 0 & 1 & 0 & 0 & 0 & 0 & 0 \\
\hline & 27,5 & 0 & 0 & 0 & 0 & 0 & 0 & 0 & 0 & 0 & 0 & 0 & 0 & 0 \\
\hline & 30,5 & 0 & 0 & 0 & 0 & 0 & 0 & 0 & 0 & 0 & 0 & 0 & 0 & 0 \\
\hline & $>32$ & 0 & 0 & 0 & 0 & 0 & 0 & 0 & 0 & 0 & 0 & 0 & 0 & 0 \\
\hline & Next & 0 & 0 & 0 & 0 & 0 & 0 & 0 & 0 & 0 & 0 & 0 & 0 & 0 \\
\hline & $\mathrm{M}$ & 0 & 0,0149 & 0 & 0 & 0 & 0 & 0 & 0 & 0 & 0 & 0 & 0 & 0 \\
\hline \multicolumn{2}{|c|}{ Total (t) } & 1 & 1 & 1 & 1 & 1 & 1 & 1 & 1 & 0 & 0 & 0 & 0 & 0 \\
\hline
\end{tabular}

Rev. Ceres, Viçosa, v. 69, n.1, p. 92-101, jan/feb, 2022 
higher increase rate to diameter for the selective cuting treatment. Furthermore, when carrying out an experiment in two areas in the state of Rio Grande do Norte, Araújo \& Silva (2010a) found that the largest increase was found to diameter at the base $(\mathrm{DAB}>8 \mathrm{~cm})$ for the selective cutting treatment.

In contrast, the work conducted by Pareyn et al. (2010) in studying five treatments in a Caatinga area in the municipality of Lagoa Salgada/RN found similar growth rates for all treatments.

When studying an area in the municipality of Macau/ RN and applying four treatments, Araújo \& Silva (2010a) found that there were differences among the treatments, with the selective cutting treatment from above and below diameter at the base presenting the highest increase rate.

It is noticed that the SCS treatment had the greatest effect on mortality, most likely motivated by the competition process which occurs among younger individuals as the highest concentration occurred in the initial diameter classes. Corroborating these results, Teresczcuch et al. (2007) observed that dead trees were also in the initial diameter classes after harvesting, when verifying two harvesting methods.

Regarding the observed growth of new species through recruitment, although some are tolerant to shading, they still benefit from new openings which occur in the canopy (Costa et al., 2007). Costa et al. (2008) stressed that regardless of the intrinsic aspects of the species, light entrance stimulates the growth of all individuals after harvest.

The differences detected in the projection for the first diameter classes are considered common, since the greatest dynamic process occurs in these classes (Lana et al., 2015). Corroborating the results of this study, Austregesilo et al. (2004) also found an underestimation in the first diameter

Table 10: Number of observed $\left(\mathrm{No}_{t}\right)$ and predicted $\left(\mathrm{Np}_{\mathrm{t}}\right)$ trees per hectare by diameter class at time $\mathrm{t}$, for $\mathrm{t}=0$ (2015), 1 (2018) and 2 (2021) and values of the Chi-squared statistic $\left(X^{2}\right)$ for the control treatment, Contendas do Sincorá National Forest, BA, Brazil

\begin{tabular}{|c|c|c|c|c|}
\hline \multirow{2}{*}{ Class center DBH } & \multicolumn{2}{|c|}{ Number of tress observed } & \multicolumn{2}{|c|}{ Number of predicted trees } \\
\hline & $N o_{0}(2015)$ & $N o_{1}(2018)$ & $N p_{1}(2018)$ & $\mathrm{Np}_{2}(\mathbf{2 0 2 1})$ \\
\hline 6,5 & 330 & 335 & 320 & 293 \\
\hline 9,5 & 103 & 108 & 97 & 67 \\
\hline 12,5 & 42 & 43 & 36 & 28 \\
\hline 15,5 & 22 & 21 & 13 & 12 \\
\hline 18,5 & 8 & 7 & 5 & 5 \\
\hline 21,5 & 6 & 9 & 6 & 6 \\
\hline 24,5 & 3 & 2 & 2 & 2 \\
\hline 27,5 & 2 & 2 & 2 & 2 \\
\hline 30,5 & 1 & 1 & 1 & 1 \\
\hline$>32$ & 1 & 1 & 1 & 1 \\
\hline \multirow[t]{2}{*}{ TOTAL } & 518 & 529 & 483 & 416 \\
\hline & & $\mathrm{X}^{2}$ & 10,53 & - \\
\hline
\end{tabular}

Table 11: Number of observed $\left(\mathrm{No}_{\mathrm{t}}\right)$ and predicted $\left(\mathrm{Np}_{\mathrm{t}}\right)$ trees per hectare by diameter class at time $\mathrm{t}$, for $\mathrm{t}=0(2015), 1(2018)$ and 2 (2021) and values of the Chi-squared statistic $\left(X^{2}\right)$ for selective cutting by species, Contendas do Sincorá National Forest, BA, Brazil

\begin{tabular}{|c|c|c|c|c|}
\hline \multirow{2}{*}{ Class center DBH } & \multicolumn{2}{|c|}{ Number of tress observed } & \multicolumn{2}{|c|}{ Number of predicted trees } \\
\hline & $N o_{0}(2015)$ & $N o_{1}(2018)$ & $N p_{1}(2018)$ & $\mathrm{Np}_{2}(\mathbf{2 0 2 1})$ \\
\hline 6,5 & 323 & 308 & 311 & 297 \\
\hline 9,5 & 95 & 104 & 93 & 69 \\
\hline 12,5 & 33 & 39 & 36 & 29 \\
\hline 15,5 & 15 & 21 & 16 & 13 \\
\hline 18,5 & 5 & 6 & 7 & 7 \\
\hline 21,5 & 6 & 9 & 3 & 3 \\
\hline 24,5 & 2 & 2 & 1 & 1 \\
\hline 27,5 & 2 & 2 & 1 & 1 \\
\hline 30,5 & 2 & 2 & 0 & 0 \\
\hline$>32$ & 1 & 1 & 1 & 0 \\
\hline \multirow[t]{2}{*}{ TOTAL } & 484 & 494 & 469 & 421 \\
\hline & & $\mathrm{X}^{2}$ & 17,29 & - \\
\hline
\end{tabular}


Table 12: Number of observed $\left(\mathrm{No}_{\mathrm{t}}\right)$ and predicted $\left(\mathrm{Np}_{\mathrm{t}}\right)$ trees per hectare by diameter class at time $\mathrm{t}$, for $\mathrm{t}=0(2015), 1(2018)$ and 2 (2021) and values of the Chi-squared statistic $\left(X^{2}\right)$ for selective cutting by diameter (DBH $>5 \mathrm{~cm}$ ), Contendas do Sincorá National Forest, BA, Brazil

\begin{tabular}{|c|c|c|c|c|}
\hline \multirow{2}{*}{ Class center DBH } & \multicolumn{2}{|c|}{ Number of tress observed } & \multicolumn{2}{|c|}{ Number of predicted trees } \\
\hline & $N o_{0}(2015)$ & $N o_{1}(2018)$ & $N p_{1}(2018)$ & $\mathrm{Np}_{2}(\mathbf{2 0 2 1})$ \\
\hline 6,5 & 134 & 234 & 233 & 230 \\
\hline 9,5 & 62 & 61 & 58 & 58 \\
\hline 12,5 & 20 & 20 & 20 & 20 \\
\hline 15,5 & 14 & 14 & 14 & 14 \\
\hline 18,5 & 6 & 6 & 6 & 6 \\
\hline 21,5 & 9 & 9 & 9 & 9 \\
\hline 24,5 & 1 & 1 & 1 & 0 \\
\hline 27,5 & 0 & 0 & 0 & 0 \\
\hline 30,5 & 0 & 0 & 0 & 0 \\
\hline$>32$ & 0 & 0 & 0 & 0 \\
\hline \multirow[t]{2}{*}{ TOTAL } & 246 & 345 & 341 & 337 \\
\hline & & $\mathrm{X}^{2}$ & 0,159 & \\
\hline
\end{tabular}

class between the real and the predicted distribution when studying a stretch of seasonal semi-deciduous forest. This same behavior was observed by Stepka et al. (2010).

The matrix transition model becomes advantageous to evaluate the diametric distribution dynamics because the quantitative elements provide an objective numerical analysis in changing the forest structure (Sanquetta et al., 2001). Corroborating this study, Cunha et al. (2002) found a compatible trend between the observed and the predicted values for diameter structure in the first measurement in his work, when using the transition matrix.

Teresczcuch et al. (2007) found satisfactory estimates in their study using the Markov chain for predicting diameter class distributions for a period of three years for different harvesting systems, as well as for control. In addition, according to the authors the Markovian method is simple and easy to apply, and also enables simulations based on data from two monitoring systems, as used in the present study.

Lastly, Teixeira et al. (2007) showed that there was no difference between the collected and predicted data with the Markov chain for the observed and projected frequencies in each diameter class.

\section{CONCLUSIONS}

In the treatments which involved suppression compared to the control, the basal area showed a tendency for recovery and growth in relation to the original area, however presenting lower growth rates than the control. The selective cutting by species directly influenced the mortality rate of individuals, which contributed to its negative balance. Mortality rates, recruitment, growth and prediction using the Markov chain revealed an important rhythm in the process of restoring vegetation in the area.

\section{ACKNOWLEDGEMENTS, FINANCIAL SUPPORT AND FULL DISCLOSURE}

The authors give thanks to the Coordenação de Aperfeiçoamento de Pessoal de Nível Superior (CAPES) for granting the scholarship, to the Conselho Nacional de Desenvolvimento Científico e Tecnológico (CNPq) for the financial support for the project (process no. 484260/20138). To ICMBio of the state of Bahia for permission to develop this research in the Contendas do Sincorá National Forest, and to the Laboratório de Ecologia e Proteção Florestal of the Universidade Estadual do Sudoeste da Bahia - UESB.

The authors inform that there is no conflict of interest in conducting the research and publication of the manuscript.

\section{REFERENCES}

Araújo LVC \& Silva JA (2010a) Unidade Experimental Assentamento Venâncio Zacarias - Macau/RN. In: Gariglio MA, Sampaio EVSB, Cestaro LA \& Kageyama PY (Eds.) Uso sustentável e conservação dos recursos florestais da caatinga. Brasília, Brazilian Forest Service. p.245-257.

Araújo LVC \& Silva JA (2010b) Unidade Experimental Fazenda Belo Horizonte - Mossoró/RN. In: Gariglio MA, Sampaio EVSB, Cestaro LA \& Kageyama PY (Eds.) Uso sustentável e conservação dos recursos florestais da caatinga. Brasília, Brazilian Forest Service. p.205-214

Austregesilo SL, Ferreira RLC, Silva JAA, Souza AL, Meunier IMJ \& Santos ES (2004) Comparação de métodos de prognose da estrutura diamétrica de uma floresta Estacional Semidecidual secundaria. Revista Árvore, 28:227-232.

Azevedo CP, Souza AL \& Jesus RM (1995) Um modelo de matriz de transição para prognose de crescimento de um povoamento natural remanescente não manejado de mata atlântica. Revista Árvore, 9:187-199.

Brasil (2006) Lei Federal No 11.284. Available at: http://www.planalto.gov.br/ccivil_03/_Ato20042006/2006/Lei/ L 11284. htm\#: : text=Disp\%C3\%B 5e\%20sobre\% 20 a\%20 gest $\%$ C $3 \%$ A $30 \% 20$ de, dezembro $\% 20$ de $\% 201972 \% 2 \mathrm{C}$ $\% 209.605 \% 2 C \% 20 d e$. Accessed on: September $20^{\text {th }}, 2019$. 
Buongiorno J \& Michie BR (1980) A matrix model of unevenaged forest management. Forest Science, 26:609-625.

Campello FB (2019) Uso sustentável integrado da biodiversidade na caatinga. Available at: http://www.sbs.org.br/destaques_usosustentavel.htm. Accessed on: June $06^{\text {th }}, 2019$.

Colpini C, Silva VSM, Soares TS, Higuchi N, Travagin DP \& Assumpção JVL (2010) Incremento, ingresso e mortalidade em uma floresta de contato ombrófila aberta/estacional em Marcelândia, Estado do Mato Grosso. Acta Amazonica, 40:549-556.

Costa DHM, Carvalho JOP \& Berg EVD (2007) Crescimento diamétrico de maçaranduba (Manilkara huheri Chevalier) após a colheita da madeira. Amazônia: Ciência e Desenvolvimento, 3:65-76.

Costa DHM, Silva JNM \& Carvalho JOP (2008) Crescimento de árvores em uma área de terra firme na Floresta Nacional do Tapajós após a colheita de madeira. Revista de Ciências Agrárias, 50:63-76

Cunha US, Machado SA, Figueiredo Filho A \& Sanquetta CR (2002) Predição da estrutura diamétrica de espécies comerciais de terra firme da Amazônia por meio de matriz de transição. Ciência Florestal, 12:109-122.

Ferraz RC, Mello AA, Ferreira RA \& Prata APN (2013) Levantamento fitossociológico em área de caatinga no monumento natural Grota do Angico, Sergipe, Brasil. Revista Caatinga, 26:89-98.

Figueiredo Filho A, Dias AN, Stepka TF \& Sawczuk AR (2010) Crescimento, Mortalidade, Ingresso e Distribuição Diamétrica em Floresta Ombrófila Mista. Revista Floresta, 40:763-776.

Gariglio MA, Sampaio EDS, Cestaro LA \& Kageyama PY (2010) Uso sustentável e conservação dos recursos florestais da caatinga. Brasília, Brazilian Forest Service. 368p.

Garlet A, Canto JL \& Oliveira PRS (2018) O Manejo Florestal Comunitário da Caatinga em Assentamentos Rurais no Estado da Paraíba. Ciência Florestal, 28:735-745.

Guerra AMNM, Pessoa MF \& Maracajá PB (2014) Estudo fitossociológico em dois ambientes da caatinga localizada no assentamento Moacir Lucena, Apodi-RN - Brasil. Revista Verde: $9: 141-150$.

IBAMA (2006) Plano de Manejo Floresta Nacional Contendas do Sincorá - Volume I. Available at: https://www.icmbio.gov.br/portal/images/stories/imgs-unidades-coservacao/contendas_do_sincora1.pdf. Accessed on: July 07 ${ }^{\text {th }}, 2020$.

IBGE (2012) Manual Técnico da Vegetação Brasileira. $2^{\text {nd }}$ ed. Rio de Janeiro, Instituto Brasileiro de Geografia e Estatística. 271p.

IBGE (2019) Brasil em síntese. Available at: https://brasilemsintese.ibge.gov.br/territorio.html. Accessed on: October $23^{\text {th }}, 2019$.

Lana MD, Pellico Netto S, Corte APD, Sanquetta CR \& Ebling AA (2015) Prognose da Estrutura Diamétrica em Floresta Ombrófila Mista. Floresta e Ambiente, 22:71-78.

Lingner DV, Oliveira YMM, Rosot NC \& Dlugosz FL (2007) Caracterização da estrutura e da dinâmica de um remanescente de Floresta com Araucária no Planalto Catarinense. Pesquisa Florestal Brasileira, 55:55-66.

Miguel A, Marimon BS, Oliveira EA, Maracahipes L \& MarimonJunior BH (2011) Dinâmica da comunidade lenhosa de uma floresta de galeria na transição Cerrado-Floresta Amazônica no Leste de Mato Grosso, em um período de sete anos (1999 a 2006). Biota Neotropica, 11:53-62.

Oliveira-Filho AT, Carvalho WAC, Machado ELM, Higuchi P, Appolinário V, Castro GC, Silva AC, Santos RM, Borges LF, Corrêa BS \& Alves JM (2007) Dinâmica da comunidade e populações arbóreas da borda e interior de um remanescente florestal na Serra da Mantiqueira, Minas Gerais, em um intervalo de cinco anos (1999-2004). Revista Brasileira de Botânica, 30:149-161.
Pantaleão JC, Soares TS, Colpini C, Silva VS \& Matricardi W (2008) Avaliação da estrutura, crescimento, mortalidade e recrutamento em uma Floresta Semidecidual Submontana na Amazônia Mato-Grossense. Amazônia: Ciência e Desenvolvimento, 4:63-78.

Pareyn FGC, Lima KC, Marques MWCF, Riegelhaupt EM \& Bacalini P (2010) Dinâmica da Regeneração da Vegetação da Caatinga na Unidade Experimental PA Recanto III - Lagoa Salgada/RN. In: Gariglio MA, Sampaio EVSB, Cestaro LA \& Kageyama PY (Eds.) Uso sustentável e conservação dos recursos florestais da caatinga. Brasília, Brazilian Forest Service. p. 229-244.

Peng C (2000) Growth and yield models for unevenaged stands: past, present and future. Forest Ecology and Management, 132:259-279.

Pereira Júnior LR, Andrade AP, Araújo KD, Barbosa AS \& Barbosa FM (2014) Espécies da caatinga como alternativa para o desenvolvimento de novos fitofármacos. Floresta e Ambiente, 21:509520 .

Riegelhaupt E, Pareyn FGC \& Bacalini P (2010) Manejo Florestal na Caatinga: Resultados da Experimentação. In: Gariglio MA, Sampaio EVSB, Cestaro LA \& Kageyama PY (Eds.) Uso sustentável e conservação dos recursos florestais da caatinga. Brasília, Brazilian Forest Service. p.256-276.

Sanquetta CR, Cunha US, Watzlawick LF \& Campos MLB (2001) Projeção da distribuição diamétrica de fragmentos de florestas semidecíduas com matriz de transição. Revista Ciências Exatas e Naturais, 3:75-85.

Santos VS, Batista APB, Aparício OS, Aparício WCS \& Lira-Guedes AC (2012) Dinâmica florestal de espécies arbóreas em uma floresta de várzea na cidade de Macapá, AP, Brasil. Revista Verde, 7:207-213.

Sawczuk AR, Figueiredo Filho A, Dias AN, Watzlawick LF \& Stepka TF (2012) Alterações na estrutura e na diversidade florística no período 2002-2008 de uma Floresta Ombrófila Mista Montana do Centro-Sul do Paraná, Brasil. Revista Floresta, 42:1-10.

Shen Y, Santiago LSMAL, Lin GJ, Lian JY, Cao HL \& Ye WH (2013) Forest dynamics of a subtropical monsoon forest in Dinghushan, China: Recruitment, mortality and the pace of community change. Journal of Tropical Ecology, 29:131-145.

Souza AL \& Soares CPB (2013) Florestas nativas: estrutura, dinâmica e manejo. Viçosa, Ed. UFV. 322p.

Stepka TF, Dias AN, Figueiredo Filho A, Machado SA \& Sawczuk AR (2010) Prognose da estrutura diamétrica de uma Floresta Ombrófila Mista com os métodos razão de movimentos e matriz de transição. Pesquisa Florestal Brasileira, 30:327-335.

Teixeira LM, Chambers J, Silva AR, Lima AJN, Carneiro VMC, Santos J \& Higuchi N (2007) Projeção da dinâmica da floresta natural de Terra-firme, região de Manaus-AM, com o uso da cadeia de transição probabilística de Markov. Acta Amazonica, 37:377-384.

Teresczcuch SM, Mac Donagh PM, Oliveira AJ, Rivero LE \& Bulfe NML (2007) Predicción de la estructura diamétrica de especies comerciales de un bosque subtropical por médio de matrices de transición. Revista Floresta, 37:71-82.

Vasconcelos ADM, Henriques IGN, Souza MP, Santos WS, Santos WS \& Ramos GG (2017) Caracterização florística e fitossociológica em área de Caatinga para fins de manejo florestal no município de São Francisco-PI. Agropecuária Científica no Semiárido, 13:329-337.

Rev. Ceres, Viçosa, v. 69, n.1, p. 92-101, jan/feb, 2022 